\title{
Private Partnership Program (PKM) Teachers Creativity SMP YPM 4 Bohar Taman Sidoarjo Through School Magazine
}

\author{
Author \\ Ardianik, Farida, Edy Widayat \\ Correspondence \\ Fakultas Ilmu Komunikasi, FKIP, Universitas Dr. Soetomo Surabaya \\ ardianik@unitomo.ac.id
}

\begin{abstract}
:
The partner of this community partnership program is SMP YPM 4 Bohar, located on Jl. Raya Bohar No. 39 Taman Sidoarjo as a container for the generation of the nation, always applies various methods and development of learning media to answer the demands of the times to produce high-quality human resources, the obstacle faced by this school is the ability of teachers in the field of journalism is still inadequate, in addition there is also no media learning that is able to accommodate the creativity of teachers and students. Therefore it is necessary to provide journalistic training to the teachers and learning media need to be made by publishing ISSN school magazines that are able to accommodate the creativity of teachers and students in writing papers. The benefits of making this school magazine are: (1) as a communication medium; (2) as a medium of creativity; 3 ) as a medium to improve writing skills; (4) as a medium for developing reading habits; (5) as a time filler; (6) as a medium for training intelligence thinking; (7) as a medium for training in organization:; (8) as a promotional media. There are three stages in implementing a solution that must be completed with a partner: 1) Training; 2) Assignment, and 3) Assistance. The results of community service as a whole can be concluded; 1) There is a significant difference before and after the training, before and after the school magazine is made, this can be seen from the results of the paper that will be loaded in the school magazine showing that teachers and students can express a variety of ideas, various ideas, thoughts , creativity, even fantasy that accompanies the development of a student's soul through various kinds of writing so that it can be read by all other students and teachers; 2) During the process of making school magazines, partners and service teams work together so that the specified targets can be implemented well. The first school magazine with the name "SY4BAR" as a place to accommodate the creativity of YPM 4 Bohar Taman Middle School teachers and at the same time as a powerful promotional media has reached the printing stage, so all activities have been completed $100 \%$.
\end{abstract}

Keywords: creativity, school magazine, journalistic, photography.

Received: 01 Agustus 2019. Accepted: 20 Agustus 2019

\section{Introduction}

From the writing side, the ability of teachers in Indonesia has not been satisfactory enough. However, on the other hand when there are teachers who have an interest in writing often constrained by the lack of facilities that are able to accommodate and accommodate their ideas (Saputra, 2015). One solution to overcome the limitations of the media that can accommodate the teacher's writing is to use school magazines or wall magazines (Dewi, 2013)

Through this school magazine media, the teacher's potential can still be sharpened so that the writings made are also more qualified. Not only that, the existence of school magazines can also be considered as a means of communication between elements in the school, both between teachers and students, employees and principals as top management in schools. Various information can be obtained and shared through the media of school magazines (Maria, 2013). The partner in this community service program is SMP YPM 4 which addresses Jalan Raya Bohar No.39 Bohar Taman Sidoarjo, this school is trying to improve the human resources of teachers through IT-based learning training, it's just that the ability of teachers in journalism is still inadequate. Learning facilities at the YPM 4 Bohar Junior High School are sufficient enough to only accommodate the creativity of teachers who have an interest in writing are often constrained by the unavailability of facilities that are able to accommodate and accommodate their ideas. The limitation of the availability of reading material that can be used as material for writing a paper, the lack of proper functioning of the library, 
this also occurs due to several factors including: (1) inadequate library conditions and not neatly arranged; (2) the lack of availability of books that interest reading teachers, and (3) the library does not function as it functions. In addition there is no confidence and lack of experience to write a paper. Because according to the YPM 4 Bohar Taman Sidoarjo Middle School teacher writing activities require energy, time, mind and attention that really and also requires skills that are not owned by everyone, the teacher's lack of understanding of scientific knowledge to skilfully write a paper, lack of motivation to write due to lack of support from friends, and from the leadership.

Based on the complaints outlined above and the results of interviews with partner school principals, it is said that schools need to hold journalistic training that will help teachers improve their creative writing skills, through publishing school magazines that aim as a forum to accommodate the teacher's writings, to increase reading interest teacher, improve teacher skills in writing papers, and for the benefit of school accreditation.

The benefits of making a school magazine are: (1) as a communication medium: through school magazines every teacher can express his ideas and ideas through a variety of writings so that all students and other teachers can read them; (2) as a medium of creativity: from the writer's point of view, the school magazine is a place to express various kinds of ideas, various ideas, thoughts, creativity, and even fantasy that accompany the development of a student's soul. From the side of the reader will get inspiration related to desires, ideals, love, longing, and various other thoughts that cannot be channelled by themselves, (3) as a medium to improve writing skills; (4) as a medium for developing reading habits; (5) as time fillers: school magazines can be used as a means by students and teachers to fill their free time, when there are empty hours, or finish teaching and learning; (6) as a medium for training intelligence thinking; (7) as a medium for training in organization: the organization of school magazines is clearly the work of students and teachers who need planning, organizing and supervision (Asezao, 2012).

An important advantage in publishing school magazines is that they can be used as a

promotional medium. It is generally understood that school magazines have a promotion function that is effective enough to introduce schools (Miyono, 2011). Readers who come from outside, can find out the advantages and advantages of the school. Not only that, readers can also understand what programs have been run by schools to improve the quality of students and teachers. In the end, the reader can judge how the quality of the school is concerned.

According to Triyono (2016) said that in school education institutions there needs to be a journalistic extracurricular whose job is to help handle the creation of school magazines, so that the existence of school magazines is maintained and consistently observed. For this reason, teacher assistance will continue. The potential of the Journalism Team must always be able to show improvement, and this potential must get more attention and better facilities, so that later they can produce works that are also potential for the school environment and surrounding communities.

\section{Method}

The stages of implementing the solution can be seen in the figure below:

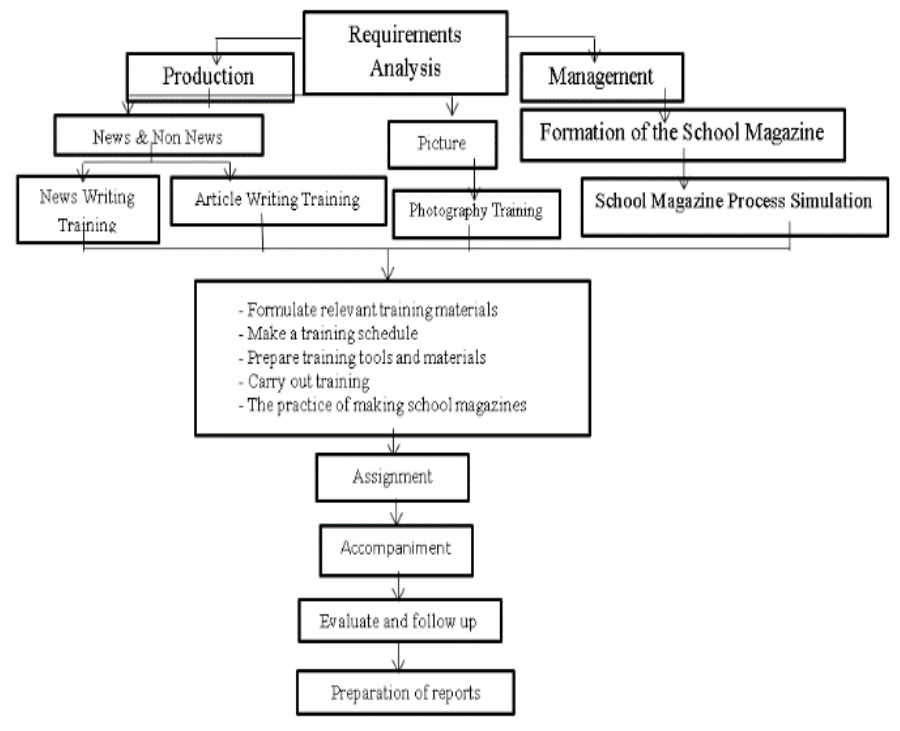

Based on the solutions offered, as well as the results of discussions with partners, the stages in implementing the solutions that must be completed with partners are three stages, namely: 1) Training; 2) Assignment, and 3) Assistance, which will be explained in detail as follows:

\section{Training}


From the needs analysis found two training groups to be carried out namely, the production training group and the management training group. The production training group consists of news writing training, article writing training and photography training, while the management training group is a training group for the formation of a school magazine team.

The training sequence to be carried out includes:

1. Management Training, which is basic training regarding the process of the formation of school magazines. This training is the beginning of the training before other training is given. The material from management training here is a theory or basic concept at the cognitive level, such as how important and interesting the school magazine is to

2. School Magazine Process Simulation, this is done so that each team member of the school magazine understands their functions and duties well. The school magazine is a school learning media that is published periodically according to the agreement and ability of the school, therefore for its sustainability it requires teamwork and solidity.

3. News Writing Training, a training on good and correct news writing techniques, how to compile reports or actual information about an event or problem to be published in a school magazine.

4. Article Writing Training, is a writing training that must be given, because the contents of writing in school magazines besides news are articles. The material in this training is starting from how to collect ideas, process articles and revise articles.

5. Photography Training, in this training the priority is how to produce a photojournalism, which is news that is stated through photographs.

\section{Assignment}

After management training and editorial team formed by members of the service 2 , then continued with the provision of training in writing articles by the chairman of the service, and training in writing news and photography by members of the service 1 . In addition to getting material from the training as explained above, the service team also give assignments to the editorial team as partners. The assignment was done by asking the editorial team to cover the news as well as to support photos and writing articles with a predetermined theme that was monitored by the service team together with students. Assignments given to the editorial team are monitored by the service team so that the tasks given can be carried out to the maximum so as to produce quality writing. The inaugural magazine as a result of this assistance will be determined through a coordination meeting between the service team and partners.

\section{Assistance}

When doing the assignment to do the reporting, the editorial team was accompanied by students and the service team. The assistance was carried out intensively with discussions and coordinating meetings to get a good and proper writing. Assistance is also carried out when making school magazines to the point of publication.

\section{Results and Discussion}

Community service activities carried out in the form of training and practice. The training is conducted in the form of lectures and discussions. Whereas in practice the service team together with partners worked together to make the school magazine in accordance with the agreed time. The community service program obtained the following results:

1. Management training which aims to increase teachers' knowledge about school magazines which includes understanding of school magazines, the benefits of school magazines, organizational management (tasks and organizational structure), editorial management (editor in chief responsibilities), the process of making school magazines (time of issue, themes, rubrics and work schedules). The rubric includes information rubric, rubric of opinion, and rubric of entertainment. Work schedule includes material collection (reporter preparation, equipment preparation, and mental preparation), material selection, editing, lay out, decorating school magazines, evaluating, and bookkeeping. At the end of the management training a school magazine editorial team was formed. 


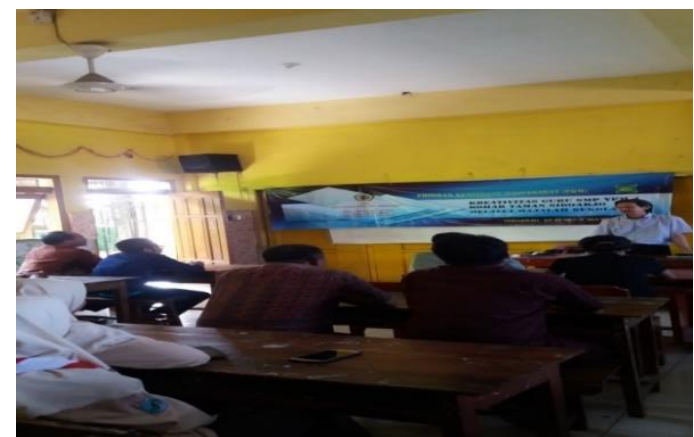

Figure 1. Photo of a member of the service team providing management training.

2. Article Writing Training aims to improve the skills and creativity of teachers in writing articles in the form of research results including the development and engineering and the results of thinking related to policies and problems in the field of education. The article text of an activity sponsored by a certain party must contain an acknowledgment containing the sponsor's funding information and a thank you to the sponsor. The manuscript has never been published in other media. The training material includes the contents of the article, the writing procedures, the ease and appreciation for the writers, the systematic writing, and the procedures for writing the reference library.

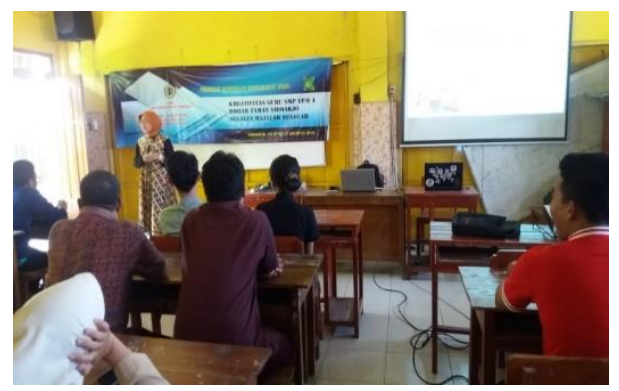

Figure 2. Photo of the leader of the service team giving training on article writing.

3. News Writing Training which aims to increase the knowledge, abilities and creativity skills of teachers about the basics of news writing techniques in the form of stories or information about warm events or events, reports of interesting actual events, and notifications. Is a training on good and correct news writing techniques, how to compile reports or actual information about an event or problem to be published in a school magazine The training material covers the basics of news writing techniques namely news understanding, three news elements (events or events, reporters and readers), the news can answer the questions five $\mathrm{W}$ (What, Who, When, Where, Why) and one $\mathrm{H}$ (How), the nature of the news, news value, types of news, news sources, how to get news, and how to write news.

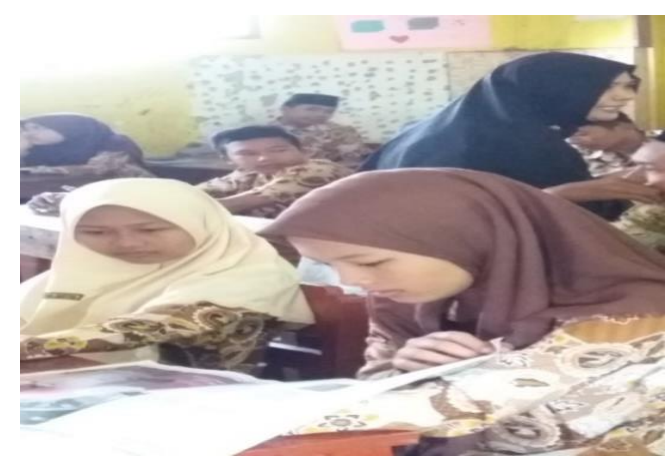

Figure 3. Photo of a member of the service team providing news writing training.

4. Photography training that aims to increase the knowledge, abilities and creativity skills of YPM 4 Bohar Middle School teachers on basic photography techniques, how to produce a journalistic photo, which is news that is expressed through photographs. Training materials include: understanding photography, getting to know the type of camera, getting to know the camera parts (lens, diaphragm, speed, focus, sharp scale, and film), camera settings for taking pictures, light problems in pictures, technical problems, choosing a camera.

5. Facilitating the Making of a School Magazine, the steps in making a school magazine are as follows:

a. Divide the editorial team and student council into several groups. The groups get the task to collect papers that will be published in school magazines

b. The service team and partners chose the best writing to be published in the school magazine 
c. The team of devotees and partners determine the name of the school magazine to be published under the name "SY4BAR" which stands for SMP YPM 4 Bohar in the first / inaugural edition.

d. The team of devotees and partners discuss the layout of school magazines to printing.

\section{Conclusion}

The implementation of the community activity program "Teacher Creativity at YPM 4 Bohar Junior High School in Sidoarjo through School Magazine" can be carried out well through a series of training and mentoring activities. Based on the overall implementation of the activities it can be concluded the results of community service are as follows.

1) Through management training, article writing, news writing and photography training, YPM 4 Bohar Taman Middle School teachers can gain a lot of knowledge and can improve their abilities and skills in making articles, news, taking photographs, management of making school magazines. This was proven through an explanation and interactive dialogue with the Dedication Team, the partners viewed positively with this dedication activity and it was very beneficial to have gained much knowledge about making school magazines.

2) There is a significant difference before and after the training, before and after the school magazine is made, this can be seen from the results of the work that will be published in the school magazine showing that teachers and students can express a variety of ideas, a variety of ideas, thoughts, power creation, even fantasy that accompanies the development of a student's soul through a variety of writings so that it can be read by all other students and teachers.

3) During the process of making school magazines, partners and service teams worked together so that the specified targets could be implemented well. The school magazine with the name "SY4BAR" as a place to accommodate the creativity of YPM 4 Bohar Taman Middle School teacher's writing and at the same time as a powerful promotional media has reached the printing stage, so all activities have been completed $100 \%$.

\section{References}

Asazeo. 2012. Fungsi Majalah Dinding (Mading)di Lingkungan Sekolah. Tersedia pada http://asezao.heck.in/fungsi-majalahdinding-mading-di-lingkun-2.xhtml (diakses pada 17 januari 2019).

Dewi, A. M. 2013. Majalah Dinding Sebagai Implementasi Kemampuan Menulis Cerpen Siswa Yang Mengikuti Ekstrakurikuler Jurnalistik DI SMPN 4 Singaraja. Jurnal Jurusan Pendidikan Bahasa dan Sastra Indonesia , Volume 1 (1), 1-15.

Maria Asssumpta Rumanti,2013. Dasar-dasar Public Relations, Cetakan ke tiga, Jakarta: Grasindo

Miyono, N. 2011. Kepuasan dan Loyalitas Pelanggan Pada Sekolah Dasar Swasta Unggul Di Semarang. Jurnal Dinamika Sosial Ekonomi, Volume 7 (2),148-163.

Saputra, A. W. 2015. Pengembangan Blok Menulis Berita Untuk Majalah Sekolah Sebagai Media Pembinaan Ekstrakurikuler Jurnalistik Bagi Siswa SMA. Jurnal Kembara, Volume 1 (2), 117-124.

Triono, Agus , dkk. 2016. Peningkatan Kapasitas Wartawan Siswa dalam Penerbitan Majalah Sekolah di SMP Mohammadiyah PK Al- Kautsar Kartasura, Jurnal Warta LPM Vol, 19 No. 2, September 2016, h. 134-140, ISSN: 1410-9344. 